3-4-2021

\title{
Toronto's 2018 Municipal Election, Rights of Democratic Participation, and Section 2(b) of the Charter
}

Jamie Cameron

Osgoode Hall Law School of York University, jcameron@osgoode.yorku.ca

Bailey Fox

Source Publication:

Constitutional Forum 30:1 (2021)

Follow this and additional works at: https://digitalcommons.osgoode.yorku.ca/scholarly_works

Part of the Constitutional Law Commons

\section{Repository Citation}

Cameron, Jamie and Fox, Bailey, "Toronto's 2018 Municipal Election, Rights of Democratic Participation, and Section 2(b) of the Charter" (2021). Articles \& Book Chapters. 2828.

https://digitalcommons.osgoode.yorku.ca/scholarly_works/2828

This Article is brought to you for free and open access by the Faculty Scholarship at Osgoode Digital Commons. It has been accepted for inclusion in Articles \& Book Chapters by an authorized administrator of Osgoode Digital Commons. 


\title{
Constitutional
}

\section{constitutionnel}

\section{Toronto's 2018 Municipal Election, Rights of Democratic Participation, and Section $2(b)$ of the Charter}

\author{
Jamie Cameron \& Bailey Fox
}

\section{Introduction}

In 2018, the City of Toronto's municipal election overlapped with a provincial election that brought a new government to office. While the municipal election ran for a protracted period from May 1 to October 22, the provincial election began on May 9 and ended about four weeks later, on June $7 .{ }^{1}$ On July 27 , after only a few weeks in office, the provincial government tabled the Better Local Government Act (BLGA) and proclaimed the Bill into law on August 14. ${ }^{2}$ The $B L G A$ reduced Toronto City Council from 47 to 25 wards and reset the electoral process, mandating that the election proceed under a different concept of representation for City Council. ${ }^{3}$

The provincial government's reorganization of City Council both ambushed and commandeered an ongoing democratic process. Though municipal reform was not part of its campaign platform, the government reconstituted City Council just a few short weeks after its

* Jamie Cameron (Professor Emerita, Osgoode Hall Law School); Bailey Fox (J.D. 2019, Osgoode Hall Law School). Professor Cameron is counsel for the Centre for Free Expression (CFE) on the appeal in City of Toronto v. Ontario at the Supreme Court of Canada. Though this article is independent of and may not represent the views of the CFE, we thank Dr. James Turk, Executive Director of the CFE, for reading and commenting on a draft of this article.

1 Office of the Premier, “Ontario Election on June 7, 2018” (8 May 2018), online: Ontario Newsroom <https:// news.ontario.ca/en/release/49542/ontario-election-on-june-7-2018>

2 SO 2018, c $11[B L G A]$.

3 Ibid, s 128(3) (providing that the 2018 municipal election "shall be conducted" as if the 25-ward division of the City was "already in effect"). 
election, and did so without notice or consultation. Neither the City, nor candidates for office, much less the electorate, were warned that the newly elected government intended to restructure Council and recalibrate an ongoing electoral process. ${ }^{4}$

In reforming Toronto City Council during an election, the provincial government upended a democratic process that was carefully planned and structured. Any election is a highly regulated undertaking and, with more than 1.8 million voters, the City of Toronto stages North America's fourth largest municipal election. ${ }^{5}$ Under the $B L G A, 22$ wards and their candidates for office disappeared and the remaining wards almost doubled in size, increasing from an average population of 61,000 to 110,000 per ward. ${ }^{6}$ A glance at the pre-and post-BLGA electoral maps readily demonstrates how radically the boundaries changed. ${ }^{7}$ In the face of dramatic and unexpected change, the City Clerk's team had to be nimble in redrawing the electoral map, reissuing ballots, and otherwise managing a complex municipal process. ${ }^{8}$

The BLGA bisected an election that was past the midway point of the campaign. The day Bill 5 was announced was also the deadline for municipal candidates to file nomination papers. By then, 544 individuals had declared their candidacy for the offices of Mayor, City Councillor, and School Trustee. ${ }^{9}$ After the BLGA was enacted on August 14, candidates had until September 14 to abandon or repurpose their campaigns under the 25 -ward model. ${ }^{10}$ That left 38 days, from September 14 to Election Day on October 22, for candidates and their teams to restart their campaigns in enlarged and unfamiliar wards, often against a new slate of competitors.

In eliminating nearly half of the City's electoral wards, the BLGA undermined the groundwork laid by candidates and their teams, who by then had been campaigning under the 47-ward model for up to three and a half months. Posters and pamphlets prepared at expense were useless, scarce campaign resources spent on non-existent wards were wasted, and doorto-door and other campaign activity was a loss. Some candidates dropped out and others adapted, transferring their campaigns to wards with different boundaries, demographics, and dynamics. In all, candidates for City Council fell from 292 to 242, for a net loss of 50, and

4 "Doug Ford's meddling in Toronto's election was a secret, off the record, backroom decision" (17 September 2018), online: Ontario NDP <https://www.ontariondp.ca/news/doug-ford\%E2\%80\%99s-meddlingtorontos-election-was-secret-record-backroom-decision>; see also Michael Morden, "The Process Around Ontario's Bill 5, which transforms the political process in Toronto, failed to meet the criteria for democratic legitimacy" (4 September 2018), online: Policy Options < $\underline{\text { https://policyoptions.irpp.org/magazines/higher- }}$ standard-required-changes-democratic-bodies/>.

5 The others are Mexico City, Los Angeles, and New York City. City of Toronto (Election Services), "2018 Municipal Election Report" online (pdf): Toronto < $\underline{\text { https://www.toronto.ca/wp-content/ }}$ uploads/2019/07/96b2-2018-Election-Report.pdf> [Municipal Report] at 5.

6 City of Toronto et al $v$ Ontario (Attorney General), 2018 ONSC 5151 [Toronto ONSC] at para 4.

7 See Municipal Report, supra note 5 at 6; see also DH Toronto Staff, “This is what Toronto's 25-ward electoral map looks like (MAPS)" (19 September 2018), online: Daily Hive News <https://dailyhive.com/toronto/ toronto-new-25-electoral-ward-2018>.

8 Municipal Report, ibid at 10 (explaining the tasks relating to election readiness under the BLGA); ibid at 22 (describing the time and effort required to realign the geographic boundaries of each ward); and ibid at 26 (explaining the demands of ballot production).

9 Ibid at 15 (also showing the breakdown of candidates for each office).

$10 \mathrm{Ibid}$. In the uncertainty arising from the emergency litigation, the deadline was extended to September 20 and 21 . 
156 candidates withdrew. ${ }^{11}$ Not surprisingly, changing the foundation of the 2018 municipal election upset and confused other participants, including the media and third party campaigners, not to mention the electorate at large.

The unilateral transformation of City Council was high-handed and disrespectful of a process under the City of Toronto Act, 2006 that established the 47-ward model shortly before the 2018 election. ${ }^{12}$ Displacing that model was described as "vindictive and mean-spirited," as well as "unfair to candidates that ran in good faith, started campaigns, raised funds, and spent money hiring staff, purchasing materials, and renting campaign offices." ${ }^{13}$ It is not surprising that the legislation provoked immediate and vociferous opposition because it cut City Council almost in half and disrupted a duly constituted election process.

The tension and uncertainty heightened through a cycle of expedited litigation. Shortly after the $B L G A$ passed, the City of Toronto and two groups of aggrieved candidates brought applications challenging the BLGA's constitutional validity. The applications were heard together and on September 9, 2018, the application judge invalidated the legislation, restoring the 47-ward electoral map and summarily dismissing the government's justification for enacting mid-election reforms, as "crickets." ${ }^{4}$ Under notice that the government would re-enact the $B L G A$ and invoke the section 33 override to protect the statute from the Charter, ${ }^{15}$ a panel of the Ontario Court of Appeal (the "stay panel") stopped the order of invalidity, pending appeal, and the election proceeded under the BLGA's 25-ward model. ${ }^{16}$ One year later, the Ontario Court of Appeal (the "appeal panel") reversed the application judge and upheld the BLGA. ${ }^{17}$ The Supreme Court of Canada granted the City of Toronto leave to appeal and will hear the appeal on March 16, 2021. ${ }^{18}$

Government action that is unfair or contrary to democratic values is not necessarily unconstitutional. In this instance, the top-down substitution of a dramatically different electoral map during an election was unprecedented, but did not reveal a clear pathway to a constitutional challenge. Ultimately, the litigation grounded the challenge in section 2(b),

11 Ibid. While the candidates for Mayor did not change (35), candidates for School Board Trustee increased slightly, from 217 to 224.

12 Toronto ONSC, supra note 6 at paras 53-54. Pursuant to its authority under the City of Toronto Act 2006, SO 2006, c11 (COTA), the City initiated the Toronto Ward Boundary Review that led to Council's adoption of the 47-ward model for City Council. Litigation arising from the proposal ended before the 2018 municipal election was scheduled to begin.

13 Sean Marshall "Why Doug Ford's plan for 25 Toronto wards is an attack on democracy" (1 August 2018), online: Marshall's Musings <https://seanmarshall.ca/2018/08/01/why-doug-fords-plan-for-25-torontowards-is-an-attack-on-local-democracy/>.

14 Toronto ONSC, supra note 6 at para77. "Crickets" is a colloquial expression that connotes absolute silence or no communication, reflecting the observation that, "in silence, only the crickets are heard". Here, the application judge used the word sarcastically and as shorthand for his view that the government completely failed to provide evidence that the violation was demonstrably justified.

15 Canadian Charter of Rights and Freedoms, Part I of the Constitution Act, 1982, being Schedule B to the Canada Act 1982 (UK), 1982, c 11 [Charter].

16 Toronto (City) v Ontario (Attorney General), 2018 ONCA 761 ["stay panel" or "stay reasons"]. On the override, see note 27 , below.

17 Toronto (City) v Ontario (Attorney General), 2019 ONCA 732 ["appeal panel" or "appeal reasons"].

18 City of Toronto $v$ Attorney General of Ontario, 2020 CanLII 23630 (SCC) [City of Toronto].The Supreme Court of Canada granted leave to appeal on March 26, 2020 and the appeal will be heard on March 16, 2021. 
maintaining that the $B L G A$ 's transformation of City Council and reduction in the number of electoral wards violated the Charter's guarantee of expressive freedom. ${ }^{19}$ At the outset, it should be noted that the BLGA implicated not one, but two conceptions of entitlement under section 2(b): one that addressed the facial validity of the statute and another that concerned the timing of the BLGA's enactment during an extant municipal election.

This primer on City of Toronto addresses misconceptions about these entitlements that led the appeal panel to dismiss the section 2(b) claim. First, a focus on the facial validity of the $B L G A$ prompted a positive rights analysis that deflected attention from the statute's impact on electoral expression. As explained below, that analysis did not apply to either of the section 2(b) claims in City of Toronto. Second, though freedom from the government's interference with electoral expression is a negative entitlement, the appeal panel failed to apply Irwin Toy's section 2(b) framework, and misconceived the claim in three critical ways. ${ }^{20} \mathrm{~A}$ principled analysis of section 2(b) leads instead to the conclusion that the BLGA's alteration of the electoral map during a municipal election violated section 2(b)'s rights of democratic participation.

Finally, the question of a just and appropriate remedy is less straightforward in the unusual circumstances of this appeal. The municipal election took place on October 22, 2018, and a 25-ward Council, as prescribed by the BLGA, has been in office since then. Though an order of invalidity is not feasible under section 52(1) of the Constitution Act, the government's interference with section 2(b) during the municipal election clearly warrants a remedy. ${ }^{21}$ It is impossible to turn the clock back to the time of the breach, but it is important for the Supreme Court to censure the violation of section 2(b) and vindicate the Charter's rights of democratic participation. In the circumstances, a declaration that the BLGA's enactment and implementation during the 2018 municipal election was an unconstitutional violation of section 2(b) of the Charter is a just and appropriate remedy under section 24(1) of the Charter. To make the point bluntly, the provincial government's sabotage of an ongoing electoral campaign was constitutionally intolerable and must be censured by the Court.

\section{II. "All that is in issue here is the timing..."22}

While the configuration of a municipal council does not ordinarily raise freedom of expression concerns, the options for a constitutional challenge on other grounds were limited. Under section 92(8) of the Constitution Act 1867, the provinces have exclusive jurisdiction, vis-à-vis the federal government, on matters of municipal government, and section 3 of the Charter,

19 Charter, supra note 15, s 91(24). Section 2 of the Charter provides that "everyone has the following fundamental freedoms, including... (b) ... freedom of expression."

20 Irwin Toy Ltd $v$ Quebec (Attorney General), [1989] 1 SCR 927, 58 DLR (4th) 577 [Irwin Toy cited to SCR]. See discussion, below. In brief, the appeal panel erred in confusing the $B L G A$ 's effects on electoral expression with a right to effective expression; in failing to acknowledge the rights of democratic participation at stake; and in applying the substantial interference test to a claim governed by Irwin Toy.

21 At the Supreme Court of Canada, the City continues to seek the BLGA's invalidation, requesting a declaration of invalidity that will be suspended until the next municipal election, when City Council would return to the status quo ante of a 47-ward model. City of Toronto, supra note 18, Factum of the Appellant in the Supreme Court of Canada at para 152.

22 Appeal panel, supra note 17 at para 45. 
which guarantees democratic rights, does not extend to municipal elections. ${ }^{23}$ With those avenues foreclosed, questions about the BLGA's constitutionality gravitated to section 2(b)'s guarantee of expressive freedom and to the doctrine of unwritten constitutional principles. ${ }^{24}$

The application judge found that the BLGA unjustifiably violated section 2(b) and declared the statute to be of no force and effect. ${ }^{25}$ Specifically, he held that the legislation infringed the section 2(b) rights of candidates because it was enacted during an election campaign; he also concluded that it violated the rights of the electorate because doubling the ward size compromised their right to vote for effective representation. ${ }^{26}$ The government responded to the application judge's decision by seeking a stay of the order invalidating the $B L G A$, and by introducing Bill 31, the Efficient Local Government Act, 2018. ${ }^{27}$ The purpose of the Bill was to re-enact the legislation and protect it from judicial scrutiny by invoking the legislative override under section 33 of the Charter. ${ }^{28}$

At the stay hearing, counsel for the Attorney General was instructed to advise the judges that the government would not enact Bill 31 if the panel granted an order preserving the $B L G A$ 's reorganization of City Council for the municipal election. ${ }^{29}$ The stay panel made that order on September 19, 2018, pronouncing that it was "not in the public interest" for the election to proceed under the application judge's "dubious ruling." ${ }^{30}$ Though it was unusual in an interim matter, the panel did not mince words, stating that the lower court ruling was "probably wrongly decided." 31

Acknowledging that the BLGA was "undoubtedly frustrating," as well as "unexpected and alarming," the stay panel described the transformation of the City's electoral map as little more than an "inconvenience" to candidates who still had "considerable time" to "strategically refocus." ${ }^{2}$ Emphasizing that the BLGA did not prohibit expressive activity and that

23 Constitution Act, 1867 (UK), 30 \& 31 Vict, c 3, s 92(8), reprinted in RSC 1985, Appendix II, No 5 grants the provinces exclusive jurisdiction over "Municipal Institutions in the Province". The text of the Charter, supra note 15, s 3 protects the right of citizens to vote in elections for the House of Commons and legislative assemblies, but not in municipal or other non-parliamentary elections.

24 This paper does not consider whether the BLGA violated the evolving doctrine of unwritten constitutional principles. See, e.g. Reference re Secession of Quebec, [1998] 2 SCR 217, 161 DLR (4th) 385; British Columbia $v$ Imperial Tobacco Ltd, 2005 SCC 49.

25 Toronto ONSC, supra note 6 at paras 21, 78 and 85.

26 Ibid at para. 20.

27 Bill 31, An Act to amend the City of Toronto Act, 2006, the Municipal Act, 2001, the Municipal Elections Act, 1996 and the Education Act and to revoke two regulations, 1st Sess, 42nd Leg, Ontario, 2018 (first reading 12 September 2018) [Efficient Local Government Act 2018]. See also, "Explanatory Note" (last visited 24 February 2021), online: Legislative Assembly of Ontario < https://www.ola.org/en/legislative-business/bills/ parliament-42/session-1/bill-31>

28 Ibid, s 456.1(1) (directing that the Act operates notwithstanding s 2 and ss 7-15 of the Charter). Section 33, which is known as the override or notwithstanding clause, authorizes legislatures to immunize statutory provisions from sections 2 and 7 to 15 of the Charter for a period of five years, after making a declaration explicitly invoking s 33. Charter, supra note 15.

29 Stay panel, supra note 16 at para 8.

30 Ibid at para 20.

31 Ibid at para 10 (explaining that, in the exigent circumstances of the application for a stay, "greater attention must be paid to the merits of the constitutional claim").

32 Ibid at para 13. 
participants were just as free to engage in electoral activities, the panel described the section 2(b) claim as a "positive entitlement to a particular platform." ${ }^{33}$ Citing Baier v Alberta ${ }^{34}$ and Delisle $v$ Canada, ${ }^{35}$ the judges held that section 2(b) does not include a right to the 47 -ward "platform" and found that the BLGA did not substantially interfere with expressive freedom. ${ }^{36}$

Almost a year after the election, a five-member panel of the Ontario Court of Appeal reversed the lower court decision and upheld the $B L G A \cdot{ }^{37}$ Miller JA's majority reasons adopted a limited conception of section 2(b) and ruled against the guarantee on every issue. He held that by conflating positive and negative rights, the application judge erroneously expanded the scope of section 2(b). ${ }^{38}$ Miller JA also agreed with the stay panel that section 2(b) does not guarantee an election based on a particular platform, or on the model of City Council that existed when the election began. As well, he rejected any suggestion that section 2(b) includes a concept of effective representation, stating that such a view "wrongly imports the content of s[ection] 3 into s[ection] 2(b)" to circumvent the Charter's failure to protect municipal elections under section $3 .{ }^{39}$

Significantly, the majority opinion concluded that the BLGA did not raise any question of negative entitlement. In reaching that conclusion, Miller JA's majority reasons all but presupposed that a violation of section 2(b) requires the direct prohibition of expressive activity; as he stated, freedom of expression is respected "in the main" if governments "simply refrain" from interfering with it. ${ }^{40}$ Under that view, the $B L G A$ did not violate section 2(b) because nothing in the legislation prevented any candidate from "saying anything he or she wished to say on any subject." ${ }^{41}$

In this way, the section 2(b) claim was reframed as a right of "effective" expression, and an affirmative entitlement falling outside the scope of section 2(b). ${ }^{42}$ As Miller JA explained, section 2(b) does not promise that "expression will retain its value," and did not require the government to maintain the expressive activity of candidates in the 47 -ward election campaign. ${ }^{43}$ The government has no constitutional duty to "promote, enhance, or even preserve the effectiveness of anyone's political expression," 44 and nor is section 2(b) concerned with government action that has the "side effect" of reducing expression's "likelihood of success." ${ }^{45}$ Under this analysis, the BLGA's side effects on electoral expression did not constitute a violation of section $2(\mathrm{~b}) .{ }^{46}$

\footnotetext{
33 Ibid at para 15.

34 Baier v Alberta, 2007 SCC 31 [Baier].

35 Delisle v Canada (Deputy Attorney General), [1999] 2 SCR 989, 176 DLR (4th) 513 [Delisle].

36 Stay panel, supra note 16 at paras $15,13$.

37 Appeal panel, supra note 17 (MacPherson and Nordheimer JJ.A, dissenting).

38 Ibid at paras 40 and 48.

39 Ibid at para 77.

40 Ibid at para 42 [emphasis in original].

41 Ibid at para 59.

42 Toronto ONSC, supra note 6 at para. 26. Despite citing Irwin Toy, the application judge erroneously applied the substantial interference test under s 2(b) (ibid at paras 37, 38). See discussion on this point, below.

43 Appeal panel, supra note 17 at para 46.

44 Ibid at para 43.

45 Ibid at paras $41,43$.

46 The majority opinion emphasized and repeated the point. See, e.g. ibid at paras 59, 60 (stating that s 2(b) does not guarantee any right to "effective" expressive or to an effective platform and adding that "the efficacy of expression - let alone prior expression - is not guaranteed by s. 2(b)").
} 
That, in short, is how the appeal panel transformed a claim of freedom from interference with an electoral process into a positive obligation on government to "enable" electoral expression or guarantee its "effectiveness." As explained below, the question of electoral expression's efficacy was beside the point because it was sufficient, under Irwin Toy's concept of breach, that the BLGA's transformation of City Council affected rights of democratic participation in an ongoing municipal election. ${ }^{47}$

Finally, Miller JA's observation that "all that is in issue here is the timing" spotted the key issue while missing the point. ${ }^{48} \mathrm{He}$ treated the statute's timing as constitutionally inconsequential, because the "alleged" impact on expressive freedom would be the same whether the BLGA was enacted during or after the election. ${ }^{49}$ Campaign activities that were simply diminished would have been "entirely for nought" if the BLGA was passed after the election. ${ }^{50}$ Even so, the timing of the $B L G A$ was hardly neutral, because it was impossible for the government to change the electoral map during an election campaign without disrupting electoral expression that is protected by section 2 (b).

Justices MacPherson and Nordheimer dissented from the majority opinion and would have upheld the lower court decision invalidating the BLGA. Justice MacPherson's reasons emphasized that during a campaign the "fundamental rules of a municipal election" - including ward boundaries, spending and donation limits, and nomination criteria - are "fixed in place." ${ }^{51}$ Once a campaign begins, these rules are "no longer in flux." 52 As he explained, free expression would be "meaningless" if the terms of the election, "as embodied in the legal framework," could be upended mid-stream..$^{53}$ He concluded, therefore, that the BLGA "substantially interfered with the right of all electoral participants to freely express themselves within the terms of the election after it had begun." ${ }^{4}$

In City of Toronto, the unusual dynamics of mid-election legislative reform obscured the relationship between the two elements of section 2(b) entitlement. While the statutory claim challenged the constitutionality of the BLGA's transformation of City Council, the electoral claim linked the statute's impact on the election to section 2(b)'s core values and rights of democratic participation. The confluence of those two entitlements set up the positive-negative rights dichotomy that dominated the Court of Appeal's analysis. The next section uncouples the two entitlements, explaining that while the BLGA's changes to City Council do not breach section 2(b), the statute's disruption of the municipal election violated the guarantee's rights of democratic participation..$^{55}$

47 It can be noted that the application judge's analysis of s 2(b) was not based on a conception of effective expression but rested, instead, on Irwin Toy and the effects branch of the purpose-effects test. Toronto ONSC, supra note 6 at para 26.

48 Appeal panel, supra note 17 at para 45.

49 Ibid (qualifying the impact on expressive freedom as "alleged").

50 Ibid.

51 Ibid at para 121.

52 Ibid.

53 Ibid at para 123 [emphasis added].

$54 \mathrm{Ibid}$ at para 128 [emphasis added]. See also ibid at paras 132-33 (explaining why Baier $v$ Alberta was not dispositive of the s 2(b) claim). On the substantial interference standard, see discussion below.

55 The concept of breach has implications for the question of remedy. Specifically, though a conclusion that the $B L G A$ was unconstitutional would result in an order invalidating the statute under s 52(1), a finding that 


\section{Section 2(b), the 2018 Municipal Election, and the BLGA}

The Supreme Court of Canada's jurisprudence confirms that freedom of expression is section 2's most diverse guarantee, because it protects all forms and content of expression, with few exceptions, and does so in a variety of settings and contexts. ${ }^{56}$ Many years ago, the Supreme Court's landmark decision in Irwin Toy established a low threshold for the question of section 2(b) breach, entrusting virtually all questions about limits on expressive freedom to the section 1 analysis. ${ }^{57}$ Under Irwin Toy, any government interference with an attempt to convey meaning is prima facie in breach of section $2(\mathrm{~b}) .^{58}$

Such a generous interpretation has at times raised concerns that the breadth of section 2(b)'s scope might "overshoot" the purposes of the guarantee. ${ }^{59}$ Under Irwin Toy's definition, section 2(b) is potentially unlimited because "[n]early everything people do creates opportunities for expression if 'expression' is viewed expansively enough.” ${ }^{60}$ As Justice LeBel acknowledged in Baier, such a broad definition invites recourse to doctrines aimed at narrowing the scope of section 2(b), including the concept of platforms and the "delicate distinction between positive and negative rights." ${ }^{\prime}$ That is precisely what happened in City of Toronto when the $B L G A$ 's plan for representation on City Council was challenged as a breach of expressive freedom.

As Miller JA's majority reasons noted, it was "uncontested" that the provincial government was free to enact the $B L G A$ "after an election, even the very next day." 62 In this regard, the application judge's conclusion that section 2(b) includes the right to "cast a vote that can result in meaningful and effective representation" overshot the mark, stretching the guarantee beyond its legitimate purposes. ${ }^{63}$ Instead, it was the BLGA's timing, not its reform of Council, that made the constitutional difference: the government could not alter City Council during an election without interfering with electoral expression and rights of democratic participation.

In large part because the litigation focussed on the BLGA's restructuring of City Council, the appeal panel made critical errors in interpreting section 2(b). First, the panel's decision misapplied and expanded the scope of positive rights analysis under section 2(b). Second,

the BLGA's timing interfered with electoral expression required a remedy under s 24(1) of the Charter. As discussed below, the only remedy that is feasible at this stage of the appeal is a declaration that the BLGA's enactment during the municipal election unjustifiably violated s 2(b)'s rights of democratic participation.

56 The jurisprudence includes claims arising from statutory prohibitions on expressive activity, civil as well as criminal, the open court principle, access to government property for expressive purposes, and restrictions on expression under the common law (i.e. defamation), among others. In addition, s 2(b) protects freedom of the press and media, including the newsgathering function and journalist-source privilege, and doctrines to address search warrants and production orders against members of the press.

57 Irwin Toy, supra note 20. See Ford v Quebec (AG), [1988] 2 SCR 712 at 765-66, 54 DLR (4th) 577 [Ford] (stating that limits on expressive freedom should be decided under s 1, not s 2(b)).

58 Irwin Toy, ibid at 969.

$59 R$ v Big M Drug Mart Ltd, [1985] 1 SCR 295 at 344, 18 DLR (4th) 321.

60 Baier, supra note 34 at para 76 (concurring opinion).

61 Ibid.

62 Appeal panel, supra note 17 at para 44.

63 Toronto ONSC, supra note 6 at para 59. 
the decision misconceived the negative entitlement by confusing government action affecting expression with a concept of effective expression. Finally, the panel's majority reasons sidelined section 2(b)'s rights of democratic participation and misapplied the substantial interference test.

\section{Freedom's Positives and Negatives}

City of Toronto does not present as an archetypal claim under section 2(b) because the BLGA neither prohibited nor inhibited expressive activity. ${ }^{64}$ As a result, the appeal panel dismissed the claim, finding that section 2(b) of the Charter was not implicated at all. As noted above, Miller JA inferred that a breach of section 2(b) all but requires a prohibition of expressive activity. ${ }^{65}$ To the contrary, Irwin Toy confirms that a breach of section 2(b) does not require or depend on an express prohibition. ${ }^{66}$ Although the application judge applied Irwin Toy and its effects test, the appeal panel dismissed Irwin Toy and turned to a positive rights analysis under Baier v Alberta.

At first impression, there is a superficial resemblance between the section 2(b) issues in City of Toronto and Baier $v$ Alberta, which addressed the constitutionality of a statute preventing school employees from running for office as a school trustee. ${ }^{67}$ In Baier, the Court found that school employees challenging their exclusion from candidacy were seeking affirmative access to a statutory platform. ${ }^{68}$ Declaring that affirmative entitlements under section 2(b) are exceptional, the Court applied a positive rights analysis and upheld the statutory exclusion. As Rothstein J explained, granting the claim would effectively constitutionalize eligibility and impose a positive obligation on government to allow school employees to run for office. ${ }^{69}$ In applying a positive rights analysis, the Court paired the emergent concept of a "statutory platform" with Dunmore $v$ Ontario's three-part test for positive rights under section $2(\mathrm{~d}){ }^{70}$

In City of Toronto, the appeal panel applied Baier because invalidating the BLGA to restore the pre-existing "platform" of 47 wards looked like a "positive entitlement to a particular platform." ${ }^{71}$ As Miller JA explained, "[g]overnment is not required to take any positive steps to provide or maintain particular platforms to enable anyone's expression." ${ }^{2}$ To that he added,

64 Appeal panel, supra note 17 at para 68 (confirming that the complainants were not "prevented" from exercising their freedom of expression).

65 Ibid at paras 42.

66 Irwin Toy stated that even if the government's purpose was not to restrict or prohibit expression, a court must still decide whether the effect of the government action was to restrict free expression. To explain, the Court stated that a rule against littering or noise that does not overtly prohibit expression may nonetheless affect expressive activity and violate s.2(b) as a result. Irwin Toy, supra note 20 at 975-76.

67 Baier, supra note 34 at para 41.

68 Ibid at para 36.

69 Ibid at para 38.

70 Dunmore v Ontario, 2001 SCC 94 [Dunmore]; Baier, supra note 34 at para 27 (stating that the exception to the general rule of no positive rights under s 2 is met where (1) a claim of underinclusion is grounded in fundamental freedoms, not in access to a particular statutory regime; (2) the claimant demonstrates that there has been a substantial interference with activity protected by $\mathrm{s} 2$; and (3) the state must be accountable for the claimant's inability to exercise the fundamental freedom).

71 Appel panel, supra note 17 at para 15.

72 Ibid at para 47. 
in unqualified terms, that a challenge to legislation that modifies a statutory platform is an assertion of a positive right. ${ }^{73}$

Baier and its statutory platform doctrine are a carve-out from Irwin Toy that apply sparingly, in limited and exceptional circumstances. In introducing the concept of a statutory platform under section 2(b), the Court expressed reservations about the positive-negative dichotomy, noting in particular that the distinction is not "always clearly made" and is not "always helpful." ${ }^{4}$ On that front, Baier and City of Toronto demonstrate how readily the distinction can be manipulated. Depending on one's point of view, Baier's school trustees were either seeking affirmative access to candidacy for office, or a negative right to be free from statutory criteria targeting them for exclusion from eligibility. While Rothstein J's majority opinion treated it as a positive claim, Justice Fish's dissent took a contrary view, characterizing the provision as an exclusion that targeted school employees. ${ }^{75}$ Meanwhile, Justice LeBel offered yet another perspective in finding the claim outside the guarantee's remit. In similar fashion, the claim in City of Toronto could be conceptualized, alternatively, as an affirmative or positive entitlement to the 47-ward platform, or as a negative right to be free from government interference "in the use of an existing platform." ${ }^{\prime 6}$

The concept of a platform is rarely invoked because the doctrine can narrow the scope of section 2(b), working against the Court's stated commitments to a generous interpretation and low threshold for breach. ${ }^{77}$ It is striking, too, that Baier incorporated Dunmore's onerous substantial interference standard into section 2(b), despite clear differences in approach between sections 2(b) and (d). ${ }^{78}$ Perhaps for those reasons, the statutory platform-Dunmore analysis has only been applied once, in Baier, and the Court subsequently adopted a cautious approach to positive rights under section 2(b). In Greater Vancouver Transportation Authority $v$ Canadian Federation of Students ("Translink"), the Court warned that the statutory platform doctrine could transform many section 2(b) entitlements into positive rights claims. ${ }^{79}$ In doing so, Deschamps J admonished that Baier should not be misconstrued to apply to all cases in which expression relies, to some degree, on government "support or enablement." The next time it was invited to apply Baier, the statutory platform doctrine, and Dunmore, the Court bluntly stated that "nothing would be gained by furthering this debate," and applied the Irwin Toy methodology instead. ${ }^{81}$ As Fish J had observed in Translink, "Baier rests on its own factual foundation and was not intended to break fresh constitutional ground." 22

73 Ibid at para 56.

74 Haig v Canada (Chief Electoral Officer), [1993] 2 SCR 995 at 1039, 105 DLR (4th) 577 [Haig].

75 Baier, supra note 34. In dissent, Justice Fish characterized the statutory provision as a prohibition and "systematic exclusion" of otherwise qualified persons from participation in an important institution of local governance (ibid at para 96).

76 Appeal panel, supra note 17 at para 55 (stating the City's position).

77 See e.g. Haig, supra note 74; Native Women's Assn of Canada v Canada (AG), [1994] 3 SCR 627, 119 DLR (4th) 224 [NWAC cited to SCR] (rejecting s.2(b) claims under a positive rights analysis).

78 Baier, supra note 34 at paras 29, 30.

79 Greater Vancouver Transportation Authority $v$ Canadian Federation of Students, 2009 SCC 31 at para 34 [Translink].

80 Ibid.

81 Ontario (Public Safety and Security) v Criminal Lawyers' Association, 2010 SCC 23 at para 31.

82 Translink, supra note 79 at para 101 (concurring opinion) [emphasis added]. 
Under Baier and Translink, a positive rights analysis applies when legislation creates a platform for expression and selectively excludes certain expressive forms or content from access to the platform. ${ }^{83}$ As such, the doctrine provides a mechanism that, in limited circumstances, can address underinclusive access to a section 2(b) statutory platform. ${ }^{84}$ That line of analysis did not apply in City of Toronto because the hallmark criterion of underinclusive access was not present. The BLGA did not limit or prohibit access to any expressive platform, did not purport to regulate or address electoral expression, and was in no way underinclusive of expressive activity. By definition, legislation that does not purport to regulate expression cannot create a statutory platform granting section 2(b) access to some and excluding others.

To compare, the legislation in Baier specifically excluded a class of individuals from candidacy, and the "expressive aspects of school trustee candidacy" were sufficient, in the Court's view, to engage section 2(b) of the Charter. ${ }^{85}$ The BLGA did not create any platform for expression and was concerned with the composition of City Council, not with matters related to electoral expression. ${ }^{86}$ Therefore, the challenge to the BLGA did not fail because the statutory platform doctrine's requirements were not met, but because constitutionalizing City Council was well outside the scope of section 2(b)'s outermost purposes. ${ }^{87}$

Ultimately, more is at stake in this appeal than the question whether Baier and the statutory platform applied to the BLGA's reorganization of City Council. There were concerning doctrinal errors in the lower court decisions that invite correction. For instance, both panels of the Ontario Court of Appeal relied on Delisle v Canada, a decision that was overruled by Mounted Police Association of Ontario v Canada (Attorney General). ${ }^{88}$ Even if Mounted Police was decided under section 2(d), the Court should confirm that Delisle no longer represents the law on positive rights, especially and a fortiori under section 2(b)'s guarantee of expressive freedom..$^{89}$ In addition, the lower courts' reliance on the substantial interference standard was a serious misstep that marginalized and discounted the section $2(\mathrm{~b})$ rights at stake.

These missteps demonstrate the importance of placing strict parameters on Baier $v$ Alberta, positive rights analysis, and the statutory platform doctrine under section 2(b). City of Toronto

83 Baier, supra note 34 at para 37 (stating that an underinclusive statutory platform is "the hallmark of a positive rights claim"); see also Translink, supra note 79 at paras 32, 35.

84 Translink, ibid at para 30.

85 Baier, supra note 34 at para 33.

86 Appeal panel, supra note 17 at para 55.

87 As Irwin Toy found, those purposes are broad and include the promotion of participation in social and political decision-making, the search for and attainment of truth, and the opportunity for individual selffulfillment through expression (supra note 20 at 876 ). As broadly as they extend, those purposes cannot incorporate a substantive concept of representation without radically altering and extending $\mathrm{s} 2(\mathrm{~b})$ 's interpretation.

88 Mounted Police Association of Ontario v Canada (Attorney General), 2015 SCC 1 at para 14 Mounted Police]., listing Delisle, supra note 35 in "Cases Cited" as overruled, and explaining the Court's decision to re-consider Delisle (ibid at para 127). In City of Toronto the appeal decision faulted the application judge for overlooking "contrary binding authority", including Delisle (Appeal panel, supra note 17 at para 64).

89 Though concerned with s 2(d) and labour relations, Mounted Police, supra note 88 rejected the analytical construct of Delisle, which treated the exclusion of the RCMP from the labour relations scheme as a positive obligations claim (i.e. the right to be included in the statutory scheme). The exclusion was an instance of underinclusion, but the Court decided in favour of the RCMP without relying on the positive-negative dichotomy. 
gives the Supreme Court an opportunity to address those errors, reinforce the exceptional nature of the Baier doctrine, and place clear boundaries on its scope and application.

\section{Irwin Toy and the Purpose-Effects Test}

The appeal panel's conflation of positive and negative entitlements was not limited to the statutory challenge, but also influenced its perception of the claim that the BLGA interfered with electoral expression. There, the majority opinion transformed a negative entitlement of freedom from interference with electoral expression into a positive right to effective expression..$^{90}$ In doing so, the majority emphasized that section 2(b) could not impose a constitutional obligation on government to promote, enhance, or preserve the value of the candidates' electoral expression. ${ }^{91}$ Yet the appeal panel could only characterize the claim of interference with electoral expression as an affirmative entitlement by confusing efficacy of expression with effects on expression, and failing to apply the effects branch of Irwin Toy's purpose-effects test.

Irwin Toy's analytical framework includes a purpose-effects test requiring the claimant to demonstrate that government action has interfered with expressive activity. ${ }^{92}$ While the purpose-effects test is bypassed in most cases, it plays a role when government action affects expressive freedom without prohibiting it. ${ }^{93}$ Under that concept of breach, the BLGA's enactment during the municipal election arguably met both branches of Irwin Toy's purpose-effects test. Though the first branch addresses provisions that target expression, a purposeful interference can also occur without an express prohibition on particular content or activity. ${ }^{94}$ In this instance, the provincial government reorganized City Council in the middle of an election, knowing that the BLGA would unavoidably have a profound impact on the ongoing electoral process. Replacing the extant model for City Council at a moment of maximum disruption in a municipal election was a misuse of legislative authority that could constitute a purposeful violation of section $2(\mathrm{~b})$.

The BLGA also violated section 2(b) under the "effects" branch of the Irwin Toy test, which recognizes that government action affecting expressive activity infringes the guarantee. This standard sets no threshold for breach because interfering with freedom is the breach, without regard to its scale, magnitude, or severity. ${ }^{95}$ In this context, enacting the $B L G A$ during the 2018 municipal election campaign inevitably impacted electoral expression because it transformed the 47-ward City Council and terminated the 47-ward election, thereby bringing electoral expression in that election to a halt. Democratic participation could and would resume, but only under the revised 25-ward model for City Council that was imposed midway through the election.

90 Appeal panel, supra note 17 at para 39 (stating that the application judge had expanded the purpose_of s 2(b) from a guarantee of freedom from interference with expression, to a guarantee that "government action would not impact the effectiveness of that expression") [emphasis in original].

91 Ibid. See e.g. paras 34, 39, 41, 43, 46-47, 60.

92 Irwin Toy, supra note 20 at 978-79 (summarizing the test).

93 Ibid at 972.

94 A blanket prohibition on expression is a purposeful interference that does not target particular activity or content.

95 Ibid at 978-79. 
Under that analysis, there can be no doubt that the $B L G A$ 's effects on electoral expression infringed section 2(b) of the Charter. To compare, Thomson Newspapers $v$ Canada found that a 72-hour ban on opinion polls at the end of a federal election had a profound impact on political expression protected by section $2(\mathrm{~b}) .{ }^{96} \mathrm{It}$ is undeniable that transforming the representative foundation of City Council in the middle of an election could only have profound and egregious consequences for electoral expression. Notably, the appeal panel did not dispute or disturb the application judge's findings in that regard. ${ }^{97}$

Nor could it be contested, as explained in the discussion below, that the further requirement of the effects test - that expressive activity align with section 2(b)'s underlying values - was satisfied. Electoral expression and democratic rights of participation are foundational values that define the core of section 2(b)'s commitment to expressive freedom. Had Irwin Toy been applied, it would have been difficult, if not impossible, for the appeal panel not to conclude that the BLGA's enactment during the municipal election violated section 2(b) of the Charter.

\section{Rights of Democratic Participation under Section 2(b)}

The section 2(b) claim in City of Toronto was unconventional, but that is because the government's interference with an active electoral process was unprecedented. It is accepted that section 3's democratic rights do not apply to municipal elections, and nor do questions of representation and "effective" representation - e.g., the number of wards and Councillors on City Council - fall within the scope of section 2(b). The application judge's attempt to migrate a guarantee of effective representation from section 3 into section 2(b) overreached and did not fall within a principled conception of expressive freedom.

Quite apart from the issue of City Council's composition, section 2(b) extends to the panoply of expressive activity that is engaged in an electoral campaign. However, the appeal panel in City of Toronto focussed on what section 2(b) does not include and gave little or no weight to what it does include. Having identified three "sound propositions" about section 2(b) that expressive activity is protected by section 2(b), voting is expressive activity, and voting is therefore protected expression - the panel gave no further consideration to electoral expression and its status under section 2(b) ${ }^{98}$ Against an uninterrupted line of authority centering it in section 2(b)'s rights of democratic participation, the majority opinion made no mention of the status of political expression under section $2(\mathrm{~b}) .{ }^{99}$ Nor did it acknowledge the voters' right

96 Thomson Newspapers Co $v$ Canada (AG), [1998] 1 SCR 877 at para 127, 159 DLR (4th) 385 [Thomson Newspapers].

97 See Appeal panel, supra note 17 at paras 35-36. In particular, the panel acknowledged that most candidates had produced campaign materials that were tied to specific wards, that time and money had been invested in campaigning in particular wards, and that time and energy spent earning voter support was lost when allegiance shifted to other candidates who were running in other wards prior to the BLGA. The panel found nonetheless that these "side effects" did not rise to the level of a breach and, moreover, were a form of affirmative entitlement.

98 Ibid at para 73.

99 See e.g. Libman $v$ Quebec (AG), [1997] 3 SCR 569, 151 DLR (4th) 385; Thomson Newspapers, supra note 96; Harper v Canada (Attorney General), 2004 SCC 33 [Harper]; R. v Bryan, 2007 SCC 12; B.C. Freedom of Information and Privacy Association v British Columbia (Attorney General), 2017 SCC 6. 
to information and to exercise a right to vote in an informed manner - both of which were placed in great uncertainty when the $B L G A$ changed the electoral map and ward boundaries.

The central problem was not that the majority opinion refused to allow section 3's concept of effective representation to cross-fertilize section 2(b). Instead of interpreting these guarantees synergistically, as complementary entitlements that reinforce the Charter's commitment to democratic participation, the majority read section 2(b) narrowly against section 3. In doing so, the panel overlooked and neglected the vital role meaningful participation plays under both guarantees. In Figueroa $v$ Canada, a case arising under section 3, Iacobucci J emphasized that "the right of each citizen to play a meaningful role in the electoral process" is also sensitive to "the full range of reasons that individual participation is of such importance in a free and democratic society." ${ }^{100} \mathrm{He}$ added that meaningful participation in the electoral process has intrinsic value that "best reflects the capacity of individual participation in the electoral process to enhance the quality of democracy in this country." 101

In addressing restrictions on third party spending limits under section 2(b), Harper $v$ Canada confirmed that meaningful participation is a value that informs both guarantees. ${ }^{102}$ As Bastarache J explained, meaningful participation is not limited to the selection of representatives under section 3 , but includes the right to exercise a vote in an informed manner, to be able to weigh the relative strengths and weaknesses of candidates, and to be reasonably informed of all the possible choices. ${ }^{103}$ In principle, Harper followed Figueroa's lead, establishing that meaningful participation and the rights of the voting electorate are also an integral part of section 2(b)'s core commitment to participation in democratic process.

In City of Toronto, the appeal panel failed to acknowledge that meaningful participation under section 3 overlaps with and informs section 2(b)'s concept of democratic participation. Though meaningful participation is at the heart of section 2(b)'s underlying values, it received no mention or consideration in the appeal panel's majority opinion. Instead, the panel's focus on the electoral expression of candidates for office overlooked the section 2(b) rights of other participants in the electoral process, including campaign teams, third party participants, and the electorate at large.

Section 2(b) is dynamically engaged during election processes, including at the municipal level. In an election campaign conducted over the span of almost six months, expressive activity and participation in civic affairs is heightened across demographics and sectors of the population. While much can change over the course of an election campaign, the rules of democratic engagement are constant: an electoral map; ridings or wards that organize the electorate and establish a scheme of representation; criteria for candidate eligibility; and detailed rules that facilitate and regulate a democratic process to ensure that it is regular, fair, and efficient. As noted, the disruption of these fundamental rules was the foundation of Justice MacPherson's dissenting opinion. It follows from the jurisprudence that the rules of engagement for a duly constituted election cannot be altered during the process, at least not without interfering

100 Figueroa $v$ Canada (Attorney General), 2003 SCC 37 at para 27 [Figueroa].

101 Ibid.

102 Harper, supra note 99.

103 Ibid at paras 70,-72. 
with section 2(b) and damaging the integrity of its democratic values. Far from discouraging that conclusion, section 3 supports and boosts it.

The Court has emphasized and confirmed that a network of synergistic values support section 2(b)'s role in promoting the integrity of democratic processes. The Court's jurisprudence recognizes that these values encompass all participants in the process, including the electorate, as individual voters and as a collective, as well as candidates and their campaign teams, political parties, and third party participants. It is not open to question that the "underlying values" step of Irwin Toy's effects test was readily and amply met in this instance. The appeal panel's failure to include these values in its section 2(b) analysis was a serious deficiency that led to the erroneous conclusion that the BLGA's impact on electoral expression during the 2018 municipal election did not violate the guarantee.

\section{Irwin Toy and the Threshold for Breach}

The lower courts, including the application judge and both appellate panels, applied the substantial interference test to the question of breach under section 2(b). ${ }^{104}$ This standard is foreign to Irwin Toy, is limited to the narrow parameters of Baier's statutory platform doctrine, and did not apply to the negative entitlement arising from the government's interference with electoral expression during an electoral a democratic process.

Historically, the Supreme Court has supported a generous interpretation of section 2(b) and a low threshold for breach, under a conception of entitlement that requires virtually all infringements of expressive freedom to be justified under section 1 of the Charter. ${ }^{105}$ As already noted, the severity of a violation does not arise under Irwin Toy because that is outside its conception of entitlement. Irwin Toy instead prescribes that government action affecting expressive freedom that is consistent with section 2(b)'s values violates the guarantee and must be justified under section 1 of the Charter. The severity of the interference might inform the section 1 analysis, but does not define or affect the preliminary question of breach under Irwin Toy.

The substantial interference test is an exceptional standard that originated in Dunmore $v$ Ontario, a decision dealing with positive obligations under section 2(d)'s guarantee of associational freedom. ${ }^{106}$ There, the standard formed part of a three-part test to determine whether the government had a positive obligation to take steps enabling the "meaningful association" of disadvantaged agricultural workers excluded from the labour relations scheme. Importing that standard in Baier created an elevated and dissonant standard for breach under section 2(b). In dissent, Justice Fish found it "most ironic" that an interpretation designed to broaden the scope of section 2(d) was invoked in Baier "for the purpose of narrowing the Court's traditionally broad interpretation of the historically and conceptually distinct" guarantee of expressive freedom. ${ }^{107}$ Unlike section 2(b), section 2(d) set an exacting threshold for breach, and

104 Toronto ONSC, supra note 6 at paras 37-38; Stay panel, supra note 16 at para 13; Appeal panel, supra note 17 at paras 62-67.

105 Ford, supra note 57.

106 Dunmore, supra note 70.

107 Baier, supra note 34 at para 100 [emphasis in original]. Justice Fish's dissent also explained why he rejected the majority opinion's conception of positive rights and incorporation of the Dunmore test in s 2(b). 
Dunmore's substantial interference test simply does not align with the underlying assumptions of the section 2(b) jurisprudence.

In City of Toronto, all three decision-makers in the Ontario courts applied this standard in error. ${ }^{108}$ To begin, the substantial interference test was not engaged under the statutory platform doctrine because the $B L G A$ did not raise any question of underinclusive access to an expressive platform. In addition and, more to the point, the test does not apply to government interference with electoral expression, which is a quintessential negative entitlement governed by Irwin Toy. Recently, a different panel of the Ontario Court of Appeal stated that "[substantial interference] has no application if the freedom of expression claim asserts a right to be free from government interference." ${ }^{109}$ As Langenfeld $v$ Toronto Police Services Board explained, any attempt to incorporate that requirement into claims based on government interference with expressive freedom would place a broad range of potential government action that interfered with freedom of expression - but not substantially - beyond Charter review. ${ }^{110}$

On further appeal, it is imperative for the Supreme Court to confirm that the substantial interference test does not apply to negative entitlements under Irwin Toy. In addition, the Court should limit its use under section 2(b), strictly reserving it to unusual circumstances where some are excluded from access to an expressive platform that is extended to others. Even so, the doctrine of statutory platforms and the threshold of substantial interference must be carefully monitored to ensure that negative entitlements are not reinterpreted as positive rights and excluded from section 2(b) for that reason.

\section{Remedying the Breach}

The unusual circumstances of City of Toronto - mid-election interference with electoral expression and rights of democratic participation, and overlapping entitlements under section 2(b) - led to confusion about the appropriate remedy in this case. The application judge, having found that the BLGA unjustifiably breached section 2(b), invalidated the legislation, effectively restoring the 47-ward model. ${ }^{111}$ While the appeal panel dismissed the claim and did not address the question of remedy, the City of Toronto has continued to seek a declaration of invalidity, including at the Supreme Court of Canada. ${ }^{112}$

Section 52(1) of the Constitution states that any legislation that violates the Charter is of no force of effect. ${ }^{113}$ By contrast, section 24(1) of the Charter is not aimed at legislation but at government action, stating that anyone whose rights have been violated by government action may apply to the court for relief. ${ }^{114}$ The panoply of remedies available under section $24(1)$ extends beyond invalidating legislation and includes declaratory relief. ${ }^{115}$

108 Supra, note 104.

109 Langenfeld v Toronto Police Services Board, 2019 ONCA 716 at para. 37.

110 Ibid at para 39.

111 Toronto ONSC, supra note 6 at paras 84-85.

112 See e.g. supra note 21.

113 Charter, supra note 15, s 52(1).

114 Ibid, s 24(1).

115 Canada (Prime Minister) v Khadr, 2010 SCC 3 at para 46 [Khadr]. 
At this stage of the appeal, the only feasible remedy is a declaration, pursuant to section 24(1), that implementing the BLGA during an election campaign violated the section 2(b)'s rights of democratic participation. The challenge to the BLGA's restructuring of City Council is not well-founded under section 2(b), and Toronto City Council has been operating with the 25 -ward model since the 2018 election. The provincial government's interference with an ongoing election campaign is another matter; on that issue, applying Irwin Toy leads to the conclusion that the BLGA's enactment during the municipal election violated section 2(b). The government's overreaching in this instance had a profound and egregious effect on a duly constituted election process. ${ }^{116}$

A remedy to prohibit and prevent the violation of Charter rights is just and appropriate under section 24(1). As the Supreme Court has previously noted, declaratory relief is "an effective and flexible remedy" that respects "the responsibilities of the executive and the courts." 117 The Court has found that declarations are effective because "there is a tradition in Canada of state actors taking Charter declarations seriously" and " $\mathrm{t}]$ he assumption underlying this choice of remedy is that governments will comply with the declaration promptly and fully." 118 A declaration in City of Toronto is an effective remedy to censure the provincial government's egregious mid-election interference and reinforce section 2(b)'s core value of democratic participation.

\section{Conclusion}

The City and candidates for office, among others, had just cause for being frustrated by the government's decision to reverse the municipal election underway, and redirect a different election under a transformed plan for City Council. Those who challenged the provincial government's action in court invoked the Constitution to protect autonomy in matters of municipal democracy. The challenge was especially compelling in the circumstances of the legislature's interference with an ongoing election process - without notice or consultation - in which candidates, campaigns, policy debates, and broad-ranging forms of democratic participation were actively engaged.

In hindsight, and with the opportunity of further appeal to the Supreme Court of Canada, the section 2(b) issues arising from these unprecedented events can be placed on a principled plane. The analysis above advances that objective by sorting out two section 2(b) entitlements that became enmeshed in the moment, during urgent and expedited litigation. Though attention focussed on invalidating the $B L G A$, the more viable claim under section 2(b) centres on the government's interference with electoral expression during an election process. Freedom from government interference that terminated the 47-ward election and replaced it with an election based on 25 wards during a campaign is a negative entitlement that falls under Irwin Toy's framework for section 2(b) analysis.

116 Section 2(b) has been the focus and crux of the analysis throughout. It is sufficient, in the context of that discussion, to adopt Justice MacPherson's s.1 analysis, which found that the government's violation of s 2(b) was not justifiable. Appeal panel, supra note 17 at para 135 (dissenting opinion).

117 Khadr, supra note 115 at paras 46-47.

118 Association des parents de l'école Rose-des-vents v British Columbia (Education), 2015 SCC 21 at para 65 [citation omitted]. 
Had that analysis been applied, the lower courts would have had little difficulty concluding that the BLGA's implementation during the election violated section 2(b) of the Charter. That conception of section 2(b) would have led to a finding of unconstitutionality and a remedy that was just and appropriate at the time of the breach. At this stage, vindicating section 2(b)'s rights of democratic participation requires the Supreme Court to grant a declaration that the BLGA's enactment and implementation during the 2018 municipal election constituted an unjustifiable interference with rights of democratic participation protected by section 2(b).

The provincial government's authority to legislate City Council's composition was subject to the Constitution and Charter of Rights and Freedoms, including section 2(b)'s guarantee of expressive freedom. In altering the structure of representation for City Council, the government could have enacted the BLGA after the election, and done so in compliance with the Charter. That timing might have been politically untenable, but the alternative of enacting the legislation during the 2018 municipal election necessarily placed the BLGA in conflict with the Charter. As a matter of constitutional law, it was not open to the government to change the electoral map during the election and violate section 2(b)'s rights of democratic participation. Had it enacted the legislation and protected it from review, as proposed by Bill 31, the government could be held politically accountable for invoking the section 33 override. The government enacted the BLGA during an election process, without regard for the Charter, and must now be held legally accountable for its unjustifiable breach of section 2(b)'s rights of democratic participation. 